\title{
E-Learning and Comprehensive School and Kindergarten Development
}

\author{
http://dx.doi.org/10.3991/ijac.v5i3.2203 \\ Line Skov Hansen ${ }^{1}$, Ole Hansen ${ }^{1}$ and Pia Guttorm Andersen ${ }^{2}$ \\ ${ }^{1}$ Aalborg University, Denmark \\ ${ }^{2}$ Gammelgaardsskolen, Åbyhøj, Denmark
}

\begin{abstract}
The content of this article includes experiences and results of a comprehensive development project for schools and kindergartens in Denmark. The project includes all pedagogical professionals within the organization and contains a professional development sequence based on among other things e-learning where pedagogical professionals collaboratively develop their common and individual practices. The article takes a look at both the challenges and potentials that have surfaced using e-learning as part of the framework for both professional and organizational development. In addition, the article proposes how the experience gathered from this existing project can be used as springboard to design new professional development projects where e-learning becomes an important element of competency development for pedagogical professionals in schools and kindergartens closely related to practice.
\end{abstract}

Index Terms-blended learning, e-learning, praxis related learning, team-based learning, school and kindergarten development.

\section{INTRODUCTION}

Over the last 10 -15 years Denmark has experienced an increasing demand for competency development and continuing education within pedagogical professions. Today we know, based on pedagogical research that skilled leaders, teachers and pedagogues is a crucial factor for well-functioning schools and daycare institutions [15], [22], [23]. One of the fastest and most effective means to elevate the quality of our schools and daycare facilities is systematic and widely accessible competency development and continuing education [17]. One challenge is, however, to establish the opportunities for this continuing professional development in a way which ensures that what is offered has value related to the practice that needs to be developed, and that the frames for this development considers flexibility in the context in which it happens [25].

Over the last decade several different initiatives for competency development and continuing education have been established for teachers, leaders, and pedagogues. The initiatives have been shorter and longer in scope, organized as "out of the house” activities or initiatives at individual institutions or individual municipalities. These initiatives have in both form and content been more or less closely related to practice. Experience though has shown that it is not always easy to apply something learned in a different context [27]. Therefore there is a need for a more conscious and goal oriented way of establishing competency development and continuing education and of finding new methods and ways of organizing this continu- ing professional development, which ensures transfer between education and work [28].

\section{E-LEARNING AND PROFESSIONAL DEVELOPMENT}

With technological development and the many different options Information and Communication Technology (ICT) offers today for collaboration and knowledgesharing [16], we (Andersen \& Hansen) have made experiences over the last 10-15 years in regards to how modules with e-learning can be intertwined with especially competency development and continuing education of teachers in the Danish public school [1], [2], [3], [4]. The fundamental learning-theoretical starting point for designing those courses has been sociocultural. From this perspective learning is viewed as situational, fundamentally socially distributed and mediated [11].

These professional development projects have often been established as initiatives with blended learning. Blended learning is a relatively new concept originating in the US and can in its broadest sense be defined as "the integration of thoughtfully selected and complementary face-to-face and online approaches and technologies" [14]. The projects have often integrated face-to-face meetings including pedagogical lectures with sequences of e-learning, where assignments, reading of articles, literature and working with case studies has been included. Another important element in the projects has been that they have all been team-based and practice-oriented and that they have been based on a problem-oriented approach to learning [1], [2], [3].

Through a problem-oriented pedagogy the aim has been to promote both community and self-organization [18]. In the different projects the participants are first of all introduced to new knowledge through for example an educational afternoon at the workplace, including a pedagogical lecture and work with cases in teams. The teams will prospectively use the knowledge from this afternoon in their continuing teamwork through the following elearning modules. The assignments of the modules have in all projects been related to the participants' practice, and the participants had to use the new knowledge to develop and change this practice [1], [2], [3], [4].

\section{LEARNING-ENVIRONMENT AND PEDAGOGICAL ANALYSIS}

In 2007 our earlier experiences with blended learning were used in a new project, which is a comprehensive research-, and development project for schools and kindergartens in Denmark. The focus in this project is on improving the learning-environment through pedagogical 
analysis made by the pedagogical staff in either kindergarten or school. The project uses a specific "Model for Pedagogical Analysis", developed by the Norwegian professor Thomas Nordahl [20]. This model is systemtheoretical. The aim by using the model is to achieve explicit understanding of the factors, which release, influence and maintain wellbeing, behavioral, and learning problems in schools or kindergartens.

The model is to be used systematically over time and implementation into the praxis of schools or kindergartens takes 3 years. Emphasis is on the pedagogical staffs' focus on the interaction between the pupil/child and the surroundings including looking critically at own teaching methods and class leadership [20]. The idea of using this model for pedagogical analysis is to create a stronger analytical and methodological basis and readiness for administrators, teachers and pedagogues in their daily work [20].

Currently, this project has had unexpected acceptance and overt the 3 years is has become the biggest continuing education project in the Danish public schools [17]. As mentioned the project began at the end of 2007 and at the beginning of 2012 more than 500 of Denmark's 1500 public schools are participating. 30.000 administrators, teachers, and pedagogues and approximately 226.000 pupils are part of the project. Every single institution, sometimes whole municipalities sign up to participate in the 3 year project, which contains a continuing education component. The cost for participation varies according to school size from between 3300 USD - 11000 USD annually per school or kindergarten. Included in the cost the school or kindergarten receives seminars, school development and network based competency development and continuing education. The teachers or pedagogues and pupils or children produce data in return to be used by the research group for systematic feedback in relation to the success of the efforts [17].

\section{COMPREHENSIVE SCHOOL AND KINDERGARTEN DEVELOPMENT}

By comprehensive school and kindergarten development is meant a developmental project, which involves all pedagogical staff in the organization. The goal by having the project include the entire organization is to develop the entire established praxis and thus obtain a better learning outcome for all children or pupils [25]. The set up distinguishes this project from initiatives based on random and uncoordinated activities [6].

It is not coincidental that the project minimum runs over 3 years and that continuing after 3 years also is possible because research related to school development indicates there is a tendency to get better results the longer systematically praxis related development is being implemented [13], [7]. Within the scope of the developmental work at individual schools and kindergartens, competency development and continuing education is an important ingredient because the pedagogical staff needs new knowledge to develop and to change existing praxis [25]. To take the model for pedagogical analysis in use and to ensure understanding of the model, the pedagogical staff needs training in the theoretical and empirical basis for the model since it is this knowledge, they must jointly put into praxis.
An important key to the success of this project has exactly been that it includes the entire pedagogical staff and that learning in the continuing education and the subsequent implementation of what is learned is team based. Through modules of e-learning the team works among other things with the systematics of the model for pedagogical analysis and the knowledge and the ongoing research it is based on. Through this work a base for the pedagogical staff is created on which they together develop a terminology for pedagogical reflection, analysis and dialogue, collaboration and knowledge sharing at their school or kindergarten. This is why it is essential that learning happens in teams and that it is related to praxis [20], [7].

\section{A RESEARCH BASED DEVELOPMENT PROJECT}

The basis for this development project where competency development and continuing education is important elements is furthermore an ongoing collaboration between research, development and pedagogical praxis. The participating schools and kindergartens supply data about pupils, administrators, teachers and teaching and so forth. Based on this the work taking place at the participating schools or kindergartens is followed by a research group and the results of the research is supplied on an ongoing basis so administrators, teachers and pedagogues can benefit from the results of their own praxis in the form of research reports, articles, books video lectures, and through a mapping portal where the individual results for each school or kindergarten are provided. The individual institutions can see which initiatives are working and why and how they are working and they can see if the overall initiative has an effect. Through this the project is not only a professional and school development laboratory, but also a research laboratory and a praxis laboratory [17].

The research group consists of researchers from both, Aalborg University and Aarhus University, Denmark and Høgskolen in Hedmark, Norway. This research group represents both quantitative and qualitative research. The quantitative part of the research consists of a digital survey where pupils, teachers and administrators answer questions about behavior, subject-matter status, relationships, the physical environment of the school and so forth. The qualitative research part consists of 3 focus interviews with pedagogical staff throughout the 3 years the project runs.

The intention of the qualitative studies is to understand how teachers experience the changes and if new pedagogical strategies have been developed in the school or kindergarten, if collaboration has qualitatively improved in addition to evaluating if the competency development and continuing education through e-learning has been beneficial. Based on the participants preferences and new research results from the quantitative and qualitative research the project develop its form and content as well as new supplemental e-learning modules, seminars which the individual school or kindergarten can choose to purchase. 


\section{PROJECT ORGANIZATION}

\section{A. The Virtual Platform}

The development project is organized around a virtual platform. The platform functions first and foremost as a kind of website for the project where you on an ongoing basis can obtain information, pedagogical material and resources to support initiatives at each individual institution. The platform is also the frame for the obligatory elearning modules, which all pedagogical staff has to complete at the beginning of the development project. For this, each school or kindergarten is assigned an e-learning space with guidance, pedagogical material, resources and exercises for each module in addition to a forum where each team can post replies and obtain responses from an external advisor. In the e-learning space there is an electronic board, a list of participating groups and the option of studying and commenting on results posted by other participating teams within the school or kindergarten. This creates transparency among colleagues and supports exchange of experience and knowledge sharing within each organization. The virtual platform furthermore is the frame for the quantitative and qualitative research, which as mentioned is associated with each school and kindergarten's involvement in working with the model for pedagogical analysis.

The virtual platform with its many functions is kind of a common frame of reference, which creates transparency and the option to communicate and share knowledge between the project and the participants. The platform has existed continuously over the last 5 years it has been developed in collaboration between technical developers from a Danish software company, profession developers, practitioners and researchers. This development has been an iterative design process [24], where improvements, changes and new developments have been made with inspiration from needs, experiences, and wishes from participating administrators, teachers, pedagogues and external advisors. The e-learning used during the project is also a tested concept which we during the last 10-15 years has developed in collaboration with participating groups of teachers within different projects [1], [2], [3], [4].

\section{B. Blended Learning}

The mandatory continued education curriculum within the project is designed as a course based on blended learning. The course begins with a 4-hour pedagogical afternoon session for all pedagogical staff at the school or kindergarten. This session takes place at the individual school or kindergarten. During this session, the participants are learning about the project and the theoretical and empirical knowledge behind it. After this session a period of 2-3 months follows where all pedagogical staff in teams is participating in a mandatory e-learning session. This session - equaling approximately 8 hours of work is planned as 4 modules. In all modules the assignments are problem-oriented and related to the pedagogical praxis, which the team collaboratively will be developing for their own organization. Through the assignments of each module the team will be working on analyzing needs for changes locally and with implementation of newly created ways of working [5].

Through the entire time with both activities and elearning the team obtains knowledge and experience about the theories, methods and the material, which the work with the model for pedagogical analysis is based upon. Via the 4 modules of e-learning, the participants work in depth with the elements of the model and, emphasis is put on themes as system work in schools, implementation of norms and rules, school-home collaboration, the importance of the learning environment in regards to pupil development, class leadership, relations between pupils and teachers and development of social competency [20].

\section{External Advising}

Each e-learning room and course has an external consultant who assists the team with responses to module questions. The external consultant - often a person possessing pedagogical/psychological competence from the local Pedagogical Psychological Consultancy Office (PPC) would be able to contribute with new perspectives and approaches to praxis which may be less obvious for both the team and individual teacher or pedagogue. The external advisor has often only peripheral knowledge of the individual school or kindergarten and as such cannot be accused of bringing own interests and needs into the discussions [20]. Through dialogues with the consultant and through the responses to the modules the participants may become aware of possible misunderstandings, necessary insights and relevant skills related to working through the e-learning modules and related to application of what was learned as it pertains to praxis.

PPC is already involved with specific schools and kindergartens as consultants. Through the project, the consultant and the pedagogical staff establish a common language and platform for the work at hand. After completing the e-learning course the team continues to implement what is learned into their environment, the consultant's role continues to be facilitating the process by participating in some of the team's face-to-face meetings and discussions.

\section{Team Based Learning}

In the development project members of the team are responsible for their internal discussions when actually meeting at their school or kindergarten, and they are responsible for communicating with their advisor through the e-learning space. E-learning within the project is based on collaboration, reflection and sharing of knowledge. Through the processes of the teamwork, new knowledge is generated which opens up new opportunities for bringing resolutions to many of the challenges of each school or kindergarten. During the e-learning the agenda for the team meeting are both decided according to the e-learning assignments, the additional resources that included in the e-learning environment and according to the subsequent reflections and reciprocal inspiration emerging within the team. The didactical design of the e-learning courses thus builds on dialogue-oriented team-learning where all participants have the opportunity to contribute and make their mark on the project. Through team learning the participants add words to what they are looking to learn. This way terminology related to the work environment becomes part of the active vocabulary of the participants. The objective is to enable the team to identify needs for change through reflection, through working with pedagogical analysis before deciding which initiatives they want to develop and implement [5].

Through the e-learning courses activities and problems supporting the participant's reflections are emphasized. 
These reflections are identified by being closely related to praxis and could be characterized as "reflections-overpraxis" [26]. Through the team's collaboration to resolve problems related to the e-learning modules and observations from daily life, the participants experiences are paired with subject-matter and pedagogical concepts. These activities are planned through e-learning and literature especially to develop new realizations based on praxis.

\section{PRAXIS RELATED E-LEARNING}

Professor Bente Elkjær, Aarhus University, Denmark argues that there is a need for e-learning courses originating in employee experiences and which let the workplace become the frame of reference for learning [12]. Based on this you could argue that continuing education of administrators, teachers and pedagogues should be folded into the organization as an ongoing process which is part of the function of the organization that cannot be separated from praxis.

A central pedagogical principle behind establishment of different continuing education projects we have worked with over the years has focused on creating connection between theory and praxis. An important element of this new project and its use of the "Model for Pedagogical Analysis" [20] has been the incorporation of e-learning. With the virtual platform and the professional development courses attached to it based on blended learning, including both e-learning, pedagogical afternoon session and physical team meetings a learning environment is created where the team together can reflect deeply on praxis related to work. Within this praxis-related collaboration with colleagues supported by a variety of different forms of ICT- based resources and frames the team works to define and resolve problems related to praxis and thus a possibility for collaboratively developing the learning environment, the individual competencies of employees, and the overall team approach for the school or kindergarten.

The didactical design of the e-learning sequence has been inspired by John Dewey (1859-1952) who sees action as fundamental for cognition and thereby learning. To participate in a continuing education sequence could with this perspective be observed as action-oriented activity. In relation to our design is has been an aim with that the curriculum has to be anchored in the experiences of the participants and in their praxis. This becomes important if participants are to experience meaning and maintain motivation for participation. Experience, according to Dewey takes place in a context, which often is social. Experience thus becomes something intrinsic and social [8]. When learning is thought of within a continuing education course it becomes important to be aware of which options exist for social interactions (both interactional and language interaction) within the frame since these options partly are determining for learning to happen.

In the assignments for the e-learning modules emphasis is put on room for action and reflection. These elements are also central for Dewey's learning concept. To understand the concept action, Dewey includes thinking related to using ideas and hypotheses, concepts and theories. Central for Dewey is that he takes into consideration that experiences can be gained within an experimentation process in which time for analysis and reflection, cause and effect, activity and consequences hereof is allotted time, again, reflection about the process and also the result of the process [9].

\section{POTENTIALS AND CHALLENGES USING E-LEARNING}

Project-related experiences point to possible developmental potentials as well as challenges using e-learning in relation to competency development and continuing education of teachers and pedagogues and in relation to collaborative development of the organization. From the qualitative research related to the work schools are doing to implement the model, the strength of the didactical design of the competency development and continuing education first of all appears to have been the relationship to everyday praxis and the focus on learning and collaborating in teams.

In order for teachers and pedagogues to be motivated and accept both the competency development and continuing education and development of their organization no matter if it happens through e-learning or not, it is important that the content of the continuing education is experienced as goal-oriented and relevant for each individual participant's daily praxis. By participating in e-learning as a team, individual learning is coupled with the social aspect. The social dimension is an important driving force for learning, because learning - among other things are enhanced in a positive social learning environment [19].

Within the mandatory e-learning course related to the project, social interaction happens primarily through the physical meetings at the school and less through the project's virtual platform. This last form of Internet based interaction could potentially be further developed. Today web 2.0 technologies as wikis or blogs could provide options for Internet based collaboration, which again could be an additional frame for social interaction and knowledge sharing in the organization. Another important benefit by increasingly using web 2.0 based technologies is that these often are open sources and thus free or cheaper to use and, that they further enhance the ability for participants to interact [10]. By using web 2.0 in the elearning courses the teachers and pedagogues could hopefully also get some of the technical skills which are required to be a 21st century teacher or pedagogue.

The potential of using a virtual platform as frame for employees professional development is partly that this form of education is both time saving and resource saving for the organization, but more important is that the employees together can participate in a praxis-related professional development course at the same time as they are working their everyday jobs. This way the competency development or continuing education is not seen as a break, taking employees away from their daily praxis. It is important that external advisors are connected to the educational sequence as well as the school development activities. The advisors can through the e-learning space and as participants in meetings give input to participants' progress activities and participate in discussions. Use of the virtual platform can thus be seen as a way in which professional development can be moved towards the participants' praxis. The results from both quantitative and qualitative research, automatically related to individual schools or kindergartens work with "The Model for Peda- 
gogical Analysis" show that administrators, teachers and pedagogues are using the learned within their own work place and thus slowly and collaboratively are working towards changing the school - or kindergarten culture [21], [5], [7].

An important potential of e-learning within the individual school or kindergarten is, that it can function as a place of getting together which could create visibility for the different activities within the individual teams to give everyone on the team insight into each other's work. Within this also lies the possibility for the e-learning space and the electronic board to be used as a discussion forum of determined shared activities where colleagues exchange and discuss ideas. Participants in the development projects have rarely or never used this option, but it could in the future be an activity, which was supported through the assignments of the e-learning modules.

The e-learning space and the virtual platform in general can support learning with different modalities as texts, sound and film etc. By this frame the project make resources and materials generally readily available. Experiences from the project though show these resources to great extents are only used through the period of elearning and in future projects more emphasis need to be put into development of a form where participants on an ongoing basis are advised about changes of the content within the virtual platform.

\section{SUMMARY AND CONCLUSION}

Framework and content are two of the important qualitative parameters in all professional development. The framework for the participants' work with the content is determining for the outcome and the experience of usability of the competency development and continuing education investment. In the same way the content helps determine the relevance and effect [4]. The project's e-learning is identified as important because content and form has a strong connection to the participants' praxis. Experiences and results with this form of didactic design can be summarized as follows:

- E-learning may assist in supporting learning in praxis communities and optimize team collaboration

- E-learning modules assignments based on a problemoriented approach to praxis can support and develop team collaboration, common language, common attitude, common praxis in the organization as well as the teacher's or pedagogue's own praxis and culture

- E-learning can be flexible in relation to time and place for the individual team

- E-learning makes it possible to create learning processes in praxis and at the same time obtain external advising

- E-learning can be flexible in regards to the theme and the advisor

- E-learning can make it possible to create cohesiveness between the pedagogical praxis and the processchanges and could in its didactic design contribute to increasing the ability for reflection and dialogue by including experiences and knowledge of others

- E-learning can limit the cost of competence development and continuing education
Experience from this specific comprehensive development project has provided both research- and experience based knowledge in relation to letting e-learning become part of the didactical design for teachers' and pedagogues' competence development and continuing education. An important element has been how competence development and continuing education using e-learning can be established as team-based activities with an understanding of learning as a process where participants learn in collaboration [19]. It is in this context important that working with the modules and its assignments happens within praxis.

Looking ahead, the experiences from this comprehensive school and kindergarten development project and its continuing education based on blended learning where elearning plays an important part could be used in new designs and projects to ensure good, systematic and widely accessible professional development necessary to develop and strengthen the pedagogical professions and thus enhance the quality of our schools and kindergartens.

\section{A NEW SCENARIO}

An entirely new initiative has emerged both through the need for continuing professional development of teachers, leaders and pedagogues and through the work over the years with different technology-based projects of competence development and continuing education: The Laboratory for Research based School Development and Pedagogical Praxis (LSP). LSP is located in Department of Learning and Philosophy, Aalborg University, Denmark and was established in November 2011.

In LSP the emphasis is on strengthening research-based development of schools and kindergartens. In LSP the laboratory research happens in everyday context. Thus this laboratory works from 'research to praxis'. LSP develops among others research-based relevant continuing education programs and competency development and continuing education as well as Master Degree options relevant to professions involved. Through LSP municipalities, schools, kindergartens and other institutions could establish collaboration around research-based progress projects, such as evaluation projects, initiatives from development and establish new PH.D.'s based on business needs.

Within these different activities and professional development options, an Internet based collaboration and delivery of research based knowledge in addition to elearning become important elements. From within the framework and content of these activities, it would be beneficial to draw on experiences and from didactic designs developed through the described project and our other previous projects [1], [2], [3], [4] where e-learning was part of the frame for the continuing professional development of teachers and pedagogues.

\section{ACKNOWLEDGMENT}

The authors would like to thank Lilli H. Jensen, Assistant Director, International Student Services, Rochester Institute of Technology for the English translation.

\section{REFERENCES}

[1] Andersen P. G. (red.) (1993): ”Computeren i lærerprocessen”. Hjælpemiddelinstituttet, afd. For teknologi, kommunikation og 
specialundervisning og Pædagogisk Psykologisk Rådgivning, Hadsten, Hinnerup og Rosenholm Kommuner.

[2] Andersen, P. G. \& Hansen, O. (1999):”Knowledge without Frontiers”. European Distance Education Network (EDEN), Proceedings of the third open classroom conference, 25th.-26th. March 1999, Balatonfüred, Hungary p. 121-125.

[3] Andersen, P. G. \& Hansen, O. (2000):”Changing Concepts and Educational Paradigm in the Frame of ODL". Networked Learning 2000, Proceedings of the second international conference, the 17th.-19th. April 2000, p. 7-12.

[4] Andresen, B. B. (2003). ”Evaluering af KVIS E-learning 2002/03 - fremadrettet uddannelse der gør en forskel”. Copenhagen: Undervisningsministeriet.

[5] Andresen, B. B. (2009): "Billeder af en udviklingsorienteret folkeskole”. Frederikshavn: Dafolo Forlag.

[6] Andresen, B. B. (2010): "Skoler i udvikling: undersøgelse af brugen af LP-modellen”. Frederikshavn: Dafolo Forlag.

[7] Andresen, B. B. (2012): "Pædagogisk analyse og kompetenceudvikling”. Frederikshavn: Dafolo Forlag.

[8] Dewey, J. (1978): "Erfaring og opdragelse”. Copenhagen: Christian Eilers' forlag.

[9] Dewey, J. (2005): ”Democracy and Education”. New York: Cosimo Classics.

[10] Dohn, N. B. \& Johnsen, L. (2009): “E-læring på web 2.0”. Copenhagen: Forlaget Samfundslitteratur.

[11] Dysthe, O. (red.) (2003): ”Dialog, samspil og læring”. Aarhus: Forlaget Klim, Pædagogiske linjer.

[12] Elkjær, B. (2002): ”E-læring på arbejdspladsen”. I: Illeris, Knud (red.). Udspil om læring i arbejdslivet, p.105-121. Roskilde: Roskilde Universitetsforlag.

[13] Fullan, M. (2007): "The new meaning of educational change”. Cassell.

[14] Garrison, D. R., \& Vaughan, N. (2008). "Blended learning in higher education”. San Francisco: Jossey-Bass, p. 148.

[15] Hattie, J. C. (2009): "Visible Learning: A Synthesis of Over 800 Meta-Analyses Relating to Achievement”. London \& New York: Routledge, Taylor\& Francis

[16] Højhastighedskomiteen (2010): ” Danmark som højhastighedssamfund). Videnskabsministeriet. http://www.itst.dk/filer/Publikationer/hoejhastighedskomiteen/hoe jhastighedeskommiteen del1/helepubl.htm

[17] Hansen, O. \& Qvortrup L. (2011): "Vejen til en bedre skole”. Cronical in Politikken the 2th. June 2011. http://politiken.dk/debat/kroniker/ECE1297869/vejen-til-en-bedreskole/

[18] Jank, W. \& Meyer, H. (2009): ”Didaktiske modeller" Copenhagen: Gyldendal

[19] Lave, J. \& Wenger, E. (2001): "Situated learning: legitimate peripheral participation”. Cambridge: Cambridge University Press, 2001

[20] Nordahl, T. (2011): ”Arbejdet med LP-modellen: beskrivelse af analysemodellen og strategier for implementering i skolen”. This booklet is the basic literature for the e-learning modules connected to the introduction of the LP-model.

[21] Nordahl, T.; Aasen, A. M.,;Sunnevåg, A-K. og Qvortrup, L. (2012): ”Resultater af brug af LP-modellen i danske folkeskoler: evaluering af arbejdet med LP-modellen 2008-2011”. Frederikshavn: Dafolo Forlag

[22] Nordenbo, S. E; Søgaard Larsen, M; Tiftikçi, N; Wendt, R. E. \& Østergaard, S. (2008): ”Lærerkompetencer og elevers læring i førskole og skole - Et systematisk review udført for Kunnskapsdepartementet, Oslo. http://dpu.dk/Everest/Publications/udgivelser\%5Cclearinghouse/2 0080508105700/CurrentVersion/Systematisk\%20review\%202\%2 01\%C3\%A6rerkompetencer.pdf?RequestRepaired=true

[23] OECD (2006):”Starting Strong II: Early Childhood Education and Care". http://www.oecd.org/document/63/0,3746,en_2649_39263231_37 416703_1_1_1_1,00.html

[24] Rogers, Preece \& Sharp (2007): "Interaction design: beyond human-computer interaction”, 2. ed., West Sussex: John Wiley \& sons, Ltd, chap. 9.

[25] Sunnevåg A-K. \& Andersen, P. G. (2010): ”Udviklingsarbejde og innovationsprocesser”. Frederikshavn: Dafolo Forlag.

[26] Schön, Donald A. (2001): ”Den reflekterende praktiker. Hvordan professionelle tænker, når de arbejder”. Aarhus: Forlaget Klim.

[27] Wahlgren, B. (2009): ”Transfer mellem uddannelse og arbejde”. Copenhagen: Nationalt Center for Kompetenceudvikling.

\section{AuTHORS}

Line Skov Hansen, Master in ICT and Learning, has been project assistant at Centre for Knowledge-Based Educational Practice, University College Nordjylland, from 2011-2012; she is now finishing a MA in Learning and Innovative Changes, Department of Learning and Philosophy, Aalborg University, Denmark (e-mail: line.skov.hansen@gmail.com).

Ole Hansen, has been Chief Psychologist at Pedagogical Psychological Consultancy Office in the municipalities of Hadsten, Hinnerup and Rosenholm from 1976-2001, the Head of the Ministry of Educations "KVIS program" from 2001-2007, leader of Centre for Knowledge-Based Educational Practice and project manager, University College Nordjylland from 2007-2011. He is now working at LSP-Laboratory for research based development of schools and pedagogic practice, Department of Learning and Philosophy, Aalborg University, Denmark (e-mail: oh@learning.aau.dk, website: www.lsp.aau.dk).

Pia Guttorm Andersen, has worked as an elearning consultant at Pedagogical Psychological Consultancy Office in the municipalities of Hadsten, Hinnerup and Rosenholm 1993-2001, she's been principal at Haarup School 2001-2007 and project manager, University College Nordjylland from 2007-2012, she is now educational leader at Gammelgaardsskolen in Åbyhøj, Denmark (e-mail: piguan@aarhus.dk, website: www.gammelgaardsskolen.dk).

This article is an extended version of a paper presented at the conference ICELW2012, held June 2012, at Columbia University, in New York, NY, USA. Manuscript received 20 July 2012. Published as resubmitted by the authors 5 August 2012. 